\title{
Evaluation System and Its Empirical Analysis of Students' Practical Ability for Application-oriented University Kun XU ${ }^{1, a}$, Rui MA, Nan ZHANG, Xin-Zhong BAO ${ }^{1, b,{ }^{*}}$ \\ ${ }^{1}$ Management college, Beijing Union University, Beijing, 100101,China agltxukun@buu.edu.cn, bxinzhongbao@vip.sina.com \\ ${ }^{\star}$ Corresponding author
}

Keyword: Application-oriented university; Students majoring in economic management; Practical ability; Interval number

\begin{abstract}
There are many literatures on college students' practical ability, but the relevant empirical research methods are very few. From the views of the basic practical ability, professional practical ability and innovative practice ability, a practical ability evaluation system is established for students majoring in economic management. And then the interval number TOPSIS method has been carried on the related empirical studies. The results show that the application of this method can effectively reduce the subjectivity of qualitative index assignment, and this method has good feasibility and validity.
\end{abstract}

\section{Introduction}

Since the medieval times in the Europe, it has been one of the most important missions for universities and colleges to cultivate talents through education. However, the higher education of China has been paying more attention on the cognitive knowledge than the practical ability which results in the separation between the talents and the social requirements and affects the employment and adaptation of students in the society. Researches on fostering the practical ability of students thus be done on three main aspects: the analysis on the content, structure and influence factors of the practical ability; the construction of an evaluation system on the practical ability which is conducted according to different standards like majors or degrees; and the building of such system to update the practical ability of the college students.

This paper seeks to establish an practical ability evaluation system of students majoring in economic management for application-oriented universities. Fuzzy comprehensive evaluation based on the interval numbers will be used in the study.

\section{The Establishment of A Practical Ability Evaluation System}

Analysis to the relevance theory shows that the practical ability of a college students usually consists of two parts: the internal and the external structure. The internal structure refers to the interests, understanding, planning ability, execution, expression and so on of a 
student and the relationships between them while the structure of the external ability is determined by the features of different majors. Both structures can be further divided into three parts: the basic practical ability, the comprehensive practical ability and the innovative practical ability to form the whole evaluation system. Based on such theory, considering the features of the economic management majored talents in application-oriented universities and the results of some talents culturing activities took place in the Beijing Union University, this paper establishes a practical ability evaluation system according to the basic practical ability, the professional practical ability and the innovative practical ability of students, as is shown in Table 1:

Table 1 The Indexes and Description of the Practical Ability Evaluation System

\begin{tabular}{|c|c|c|c|c|c|}
\hline $\begin{array}{l}\text { Destination } \\
\text { Layer }\end{array}$ & $\begin{array}{l}\text { First-class } \\
\text { Indexes }\end{array}$ & $\begin{array}{l}\text { Second-class } \\
\text { Indexes }\end{array}$ & $\begin{array}{c}\text { Index } \\
\text { Weight }\end{array}$ & $\begin{array}{c}\text { Index } \\
\text { Number }\end{array}$ & Index Description \\
\hline \multirow{7}{*}{$\begin{array}{l}\text { Indexes of } \\
\text { the Practical } \\
\text { Ability of } \\
\text { Economic } \\
\text { Management } \\
\text { Majored } \\
\text { Students }\end{array}$} & \multirow{4}{*}{$\begin{array}{c}\text { Innovative } \\
\text { Practical } \\
\text { Ability }\end{array}$} & $\begin{array}{l}\text { Innovative } \\
\text { Consciousness } \\
\text { and Ability of } \\
\text { Thinking }\end{array}$ & 0.0653 & $\mathrm{C} 1$ & $\begin{array}{l}\text { Evaluation on the critical } \\
\text { thinking, innovation, } \\
\text { imagination, logical thinking, } \\
\text { etc. }\end{array}$ \\
\hline & & $\begin{array}{c}\text { Ability of } \\
\text { Leadership and } \\
\text { Organization }\end{array}$ & 0.0972 & $\mathrm{C} 2$ & $\begin{array}{l}\text { Position in the class, student } \\
\text { societies and student activities }\end{array}$ \\
\hline & & $\begin{array}{l}\text { Interdisciplinary } \\
\text { Ability }\end{array}$ & 0.0641 & C3 & $\begin{array}{l}\text { Learning and application of } \\
\text { knowledge like Computer } \\
\text { Science, Economic, } \\
\text { Management, Engineering, } \\
\text { Humanities, Law and son on }\end{array}$ \\
\hline & & $\begin{array}{c}\text { Participation of } \\
\text { Innovative and } \\
\text { Practical } \\
\text { Activities } \\
\end{array}$ & 0.0826 & C4 & $\begin{array}{l}\text { Results of various competitions } \\
\text { on profession and of innovation } \\
\text { and entrepreneurship }\end{array}$ \\
\hline & \multirow{3}{*}{$\begin{array}{l}\text { Professional } \\
\text { Practical } \\
\text { Ability }\end{array}$} & $\begin{array}{l}\text { Fundamental } \\
\text { Knowledge and } \\
\text { Professional } \\
\text { Skills }\end{array}$ & 0.0462 & C5 & Grades on fundamental classes \\
\hline & & $\begin{array}{l}\text { Ability of } \\
\text { Applying } \\
\text { Professional } \\
\text { Knowledge } \\
\end{array}$ & 0.0929 & C6 & $\begin{array}{l}\text { Grades on professional training } \\
\text { classes and practice classes }\end{array}$ \\
\hline & & $\begin{array}{l}\text { Ability of } \\
\text { Expanding }\end{array}$ & 0.0552 & C7 & $\begin{array}{l}\text { Paper publishing, summer social } \\
\text { practice and professional }\end{array}$ \\
\hline
\end{tabular}




\begin{tabular}{|c|c|c|c|c|}
\hline & $\begin{array}{l}\text { Professional } \\
\text { Knowledge }\end{array}$ & & & certifications \\
\hline & $\begin{array}{c}\text { Professional } \\
\text { Ethics and } \\
\text { Personal } \\
\text { Integrity }\end{array}$ & 0.0558 & C8 & $\begin{array}{l}\text { Comprehensive evaluations on } \\
\text { the attitude towards work, job } \\
\text { and personal qualities }\end{array}$ \\
\hline \multirow{7}{*}{$\begin{array}{c}\text { Basic } \\
\text { Practical } \\
\text { Ability }\end{array}$} & Learning Ability & 0.0436 & C9 & $\begin{array}{l}\text { Comprehensive evaluation on } \\
\text { learning consciousness, habit } \\
\text { and approaches }\end{array}$ \\
\hline & $\begin{array}{c}\text { Communication } \\
\text { Ability }\end{array}$ & 0.0698 & $\mathrm{C} 10$ & $\begin{array}{l}\text { Comprehensive evaluation on } \\
\text { communication skills and } \\
\text { interpersonal relationship }\end{array}$ \\
\hline & $\begin{array}{l}\text { Cooperation } \\
\text { Ability }\end{array}$ & 0.0825 & $\mathrm{C} 11$ & $\begin{array}{l}\text { Evaluation on team spirit and } \\
\text { cooperation skills }\end{array}$ \\
\hline & $\begin{array}{c}\text { Adaptation } \\
\text { Ability } \\
\end{array}$ & 0.0582 & $\mathrm{C} 12$ & $\begin{array}{l}\text { Ability to adapt to a new } \\
\text { environment and play the role }\end{array}$ \\
\hline & \begin{tabular}{|c|} 
Ability of Using \\
Computers and \\
Searching for \\
Information \\
\end{tabular} & 0.0572 & $\mathrm{C} 13$ & $\begin{array}{l}\text { Comprehensive evaluation on } \\
\text { the ability to use computer, } \\
\text { search for information and } \\
\text { process text }\end{array}$ \\
\hline & Writing Ability & 0.0754 & C14 & $\begin{array}{l}\text { Writing ability of research } \\
\text { reports, working reports and } \\
\text { project plans }\end{array}$ \\
\hline & $\begin{array}{l}\text { Foreign } \\
\text { Language } \\
\text { Ability }\end{array}$ & 0.0540 & $\mathrm{C} 15$ & $\begin{array}{l}\text { Based on the test grade of } \\
\text { CET4\&6 }\end{array}$ \\
\hline
\end{tabular}

The Evaluation Approach Based on Interval Number TOPSIS and Index Assignment The Selection of Evaluation Approaches

When conducting empirical evaluation on the practical ability of students, three aspects are involved: the weighting of indexes, the assignment of indexes and the selection of evaluation approaches.

As to the weighting of indexes, this paper adopted the commonly used analytic hierarchy process in the multi-attribute decision-making. To reduce the subjectivity of results, the weighting of indexes is conducted by five staff of teaching and employment management using analytic hierarchy process, making the average weights of the five staff the weights of indexes. The final weights of the indexes are provided in the Table 1. 
As to the assignment of indexes, since most of the indexes are qualitative, fuzzy evaluation is often adopted in such comprehensive evaluation, with numbers 1-10 to represent the value of indexes and the level of abilities. The bigger the number, the higher the level of the ability will be. However, if the valuator does not know the student who is evaluated well or he/she has not very much opportunities to perform some of the abilities, the accuracy of values the valuator given will be affected. Under this circumstance, the valuator can evaluate the abilities of the students with interval numbers. For example, the interval number $[6,8]$ represents that the value of the student who is evaluated is between $6-8$, which can reduce the subjectivity of values.

As to the election of the evaluation approaches, considering that interval numbers are employed when assigning indexes, we have chosen interval number TOPSIS method to carry on the comprehensive evaluation of the practical ability of the college students. TOPSIS method is widely adopted in the multi- indexes evaluation.

\section{The Assignment Approach of the Indexes}

The assignment of the indexes of the Practical Ability of Economic Management Majored Students here is also conducted with interval numbers. In the 15 indexes in Table 1, we definite the Participation of Innovative and Practical Activities as C4, the Fundamental Knowledges and Professional Skills as C5, the Ability of Applying Professional Knowledges as C6, the Ability of Expanding Professional Knowledges as C7, and the Foreign Language Ability as C15 which are objective indexes that can be evaluated by the test grades, certifications and the grades of CET4\&6. The rest of the indexes are subjective ones that can be evaluated by the valuator with interval numbers.

\section{Empirical Analysis of the Practical Ability of Students Majoring in Economic Management}

\section{Sample Selecting and Rules Making}

The Empirical Analysis here is sampled by the graduates of year 2017 which has 30 students in total.

The five objective indexes, the Participation of Innovative and Practical Activities(C4), the Fundamental Knowledges and Professional Skills(C5), the Ability of Applying Professional Knowledges(C6), the Ability of Expanding Professional Knowledges(C7) and the Foreign Language Ability(C15), are evaluated by headteacher according to the GPA, certification of competition and the test grade of TEM4\&6 of students. The rest of ten indexes are evaluated by other 22 students in the class within 1-10 points. To erase some abnormal influence, the lowest three points and the highest three ones are eliminated, leaving the lowest point and the highest point of the remaining 16 students as the interval number of evaluation. For example, after eliminating the highest and the lowest six points, the highest one and the lowest one of 
the remaining points are 9 and 6, so the interval number of the evaluation of the student is $[6,9]$.

\section{The Original Decision Matrix}

Under the rules stated in Table 2, The original decision matrix of the practical ability evaluation of the eight students can be formed after having the points of the headteacher and other classmates. Due to limited length, the original data is left out.

\section{The Decision Matrix with Standardized Weight}

Considering that there may be a large gap between the value of the objective indexes and the subjective indexes, the decision matrix has to be standardized first. We employed the standardizing approach for benefit type interval numbers since these indexes are all benefit type.

We then get a Decision Matrix with Standardized Weight after considering the weight of the indexes. Due to limited length, the original data is left out.

\section{The Positive Ideal Solution and Negative Ideal Solution of the Indexes}

The definition of the interval number positive ideal solution and negative ideal solution:

$$
\begin{gathered}
\tilde{y}_{j}^{+}=\left[y_{j}^{+^{L}}, y_{j}^{+^{U}}\right]=\left[\max _{i}\left(y_{i j}^{L}\right), \max _{i}\left(y_{i j}^{U}\right)\right], j \in M . \\
\tilde{y}_{j}^{-}=\left[y_{j}^{-L}, y_{j}^{-U}\right]=\left[\begin{array}{lll}
\min _{i}\left(y_{i j}^{L}\right), \min _{i}\left(y_{i j}^{U}\right)
\end{array}\right], j \in M .
\end{gathered}
$$

Then we get the results of the positive ideal solution and negative ideal solution of the indexes.

\section{The Results of the Comprehensive Evaluation}

To be specific, first we should calculate the distance of the student to be evaluated to the positive ideal point and the negative ideal point respectively, then the accessible degree of each student towards the ideal point and put the results in order according to the calculation of the accessible degree.

The formulas of the distance of the student to be evaluated to the positive ideal point and the negative ideal point are represented by interval numbers as follow:

$$
\begin{gathered}
D_{i}^{+}=\sum_{j=1}^{m}\left\|\tilde{y}_{i j}-\tilde{y}_{j}^{+}\right\|=\sum_{j=1}^{m}\left[\left|y_{i j}^{L}-y_{j}^{+L}\right|+\left|y_{i j}^{U}-y_{j}^{+U}\right|\right], \quad i \in N, \\
D_{i}^{-}=\sum_{j=1}^{m}\left\|\tilde{y}_{i j}-\tilde{y}_{j}^{-}\right\|=\sum_{j=1}^{m}\left[\left|y_{i j}^{L}-y_{j}^{-L}\right|+\left|y_{i j}^{U}-y_{j}^{-U}\right|\right], \quad i \in N .
\end{gathered}
$$

Then according to the calculation of the distance of the student to the positive ideal point and the negative ideal point, the formula of the accessible degree of each students to the ideal points are as follow:

$$
c_{i}=\frac{D_{i}^{-}}{D_{i}^{+}+D_{i}^{-}}, \quad i \in N
$$


So we can put the evaluation results of the practical ability of the students in order with the above values which are ranked from larger number to smaller number.

\section{Conclusion}

Developing the practical ability of the students is of high priority to the universities in China, especially to the application-oriented ones. With the advancing of the massive entrepreneurship and innovation initiative, the practical ability of the students is of great importance. The current study, however, have failed to do empirical researches on the it, thus this paper establishes a comprehensive evaluation system on the practical ability of the students majoring in the economic management in the application-oriented universities, and by employing the interval number TOPSIS method, carries on the empirical research. The results show that the evaluation system based on the interval number TOPSIS method is scientific and operable, and can reduce the subjectivity of indexes assignment caused by existing too much qualitative indexes.

\section{Acknowledgment:}

This research was financially supported by Beijing United University Talents Strong School Optimization Program (BPHR2017DS11).

\section{References}

[1] Zhao Jianhua, The Definition, Structure and Influence Factors of the Practical Ability of College Students, China Higher Education, 2009.7:67-69.

[2] Liang Wenling, Gao Hongjing, Empirical Research on the Practical Ability of the Undergraduate Marketing Talents, Education Expolration, 2009.10:72-74.

[3] Xie Yong, Zhang Tianping, Fang Yu, Exploration on the Establishing of Practical Ability Evaluation System for Students of Automation, Experimental Technology and Management, 2011,28(1): 12-15.

[4] Yang Lei, Liao Guojiang, Basic Inferences on Practical Ability Evaluation for the Fulltime Master of Engineering, Higher Engineering Education Research, 2015.5: 144-148.

[5] He Wanguo, Qi Xingui, On the Formation Mechanism of College Students' Practical Ability, Higher Education Research, 2010,31(10): 62-66. 